Бюллетень Почвенного института им. В.В. Докучаева. 2016. Вып. 84.

УДК 631.413:631.445.53

СТЕПЕНЬ ВЫРАЖЕННОСТИ СОЛОНЦОВОГО ПРОЦЕССА В ЦЕЛИННЫХ И АГРОГЕННОИЗМЕНЕННЫХ ПОЧВАХ СОЛОНЦОВЫХ КОМПЛЕКСОВ ЛЕСОСТЕПНОЙ И СУХОСТЕПНОЙ ЗОН

() 2016 г. И. Н. Любимова ${ }^{1}$, И. А. Салпагарова ${ }^{2}$, В. В. Хан

${ }^{1}$ Почвенный институт им. В.В. Докучаева, Россия, 119017, Москва, Пьюевский пер., 7, стр. 2

e-mail: lubimova@agro.geonet.ru

${ }^{2}$ МГУ им. М.В. Ломоносова, Россия, 119991, Москва, Ленинские горы

Приведена сравнительная оценка степени выраженности солонцового процесса в почвах солонцовых комплексов лесостепной и сухостепной зон. Проанлизированы целинные и агрогенноизмененные солонцы и солонцеватые почвы с разным содержанием обменного натрия и степенью гидроморфизма из Костанайской (Республика Казахстан), Астраханской, Воронежской, Волгоградской, Омской, Новосибирской областей. Изучены мелиорированные солонцы как с полностью разрушенным солонцовым профилем, так и с частично сохранившимся солонцовым горизонтом. Для этих целей использовали специальный показатель - балл $B$, предложенный Н.Б. Хитровым. Показано, что в целинных автоморфных почвах сухостепной зоны солонцовый процесс в настоящее время слабо выражен. После мелиорации этих почв создающиеся физико-химические условия не способствуют реставрации солонцового процесса. В луговостепных солонцах сухостепной и особенно лесостепной зон солонцовый процесс в настоящее время активен. Мелиорация этих почв улучшает свойства почв, но не настолько, чтобы полностью устранить физикохимические условия для реставрации солонцового процесса. Различия в постмелиоративном развитии солонцов в разных зонах связано с исходной степенью выраженности солонцового процесса в целинных почвах в настоящее время.

Ключевые слова: солонцы, солонцеватые почвы, солонцовый процесс, лесостепная зона, сухостепная зона.

DOI: $10.19047 / 0136-1694-2016-84-46-60$

Вопросы антропогенной эволюции почв и почвенного покрова в наше время приобретают все большее внимание. Значительному агрогенному воздействию подвергались почвы под вли- 
Бюллетень Почвенного института им. В.В. Докучаева. 2016. Вып. 84.

янием коренных мелиораций. К подобным объектам относятся почвы солонцовых комплексов. По мнению Ю.П. Паракшина, “ни один почвенный объект, ни один генетический тип не претерпел столь мощного антропогенного воздействия в течение короткого времени, как это произошло с солонцовыми комплексами... в 60-80 годы прошлого века" (2008, с. 75). Изучение направленности эволюции мелиорированных почв солонцовых комплексов имеет большое теоретическое и практическое значение для России, площадь солонцовых земель в которой 30 млн га.

Исследованиями последних лет показано, что после мелиорации солонцов сухостепной зоны солонцовый горизонт не восстанавливается, отсутствуют микропроявления иллювиирования илистой фракции. Последнее является одним из основных признаков солонцового процесса (Любимова, 2003; Бабушкин и др., 2007; Новикова и др., 2009). В то же время в мелиорированных солонцах лесостепной зоны по граням структурных отдельностей наблюдается образование органо-глинистых кутан (Семендяева, 2007; Хитров, Чевердин, 2009).

По нашему мнению, наблюдаемые различия в постмелиоративном развитии солонцов в разных зонах может быть связано с исходной степенью выраженности солонцового процесса в целинных почвах в настоящее время.

Хорошо известно, что степень пептизации глинистого материала зависит от содержания обменного натрия в почвенном поглощающем комплексе и концентрации легкорастворимых солей в почвенном растворе (Грачев, Корнблюм, 1997; McNeal et al., 1966; Rhoades et al., 1969; Naghohinen-Pour et al., 1970; Bresler et al., 1982). Основываясь на опыте предыдущих исследователей, Н.Б. Хитров (2004) разработал специальный показатель для оценки физико-химических условий развития солонцового процесса, который выражается в баллах (балл $B$ ). Он выделяет три градации степени выраженности солонцового процесса: 1) солонцовый процесс отсутствует, если балл $B=0$ и нет морфологических признаков солонцового горизонта; 2) выражен слабо - балл $B<4$; 3 ) солонцовый процесс выражен сильно при $B>4$.

Величину балла $B$ получают с использованием диаграммы, представляющей собой зависимость между содержанием обменного натрия (в процентах от емкости катионного обмена) и вели- 
Бюллетень Почвенного института им. В.В. Докучаева. 2016. Вып. 84.

чиной удельной электропроводности. Электропроводность определяют двумя способами: 1) непосредственно путем измерения удельной электропроводности в вытяжке из водонасыщенной почвенной пасты при влажности, соответствующей нижней границе текучести; 2) расчетным путем, на основе эмпирического регрессионного уравнения (Хитров, Понизовский, 1990).

Цель работы - дать оценку степени выраженности современного солонцового процесса в целинных солонцах и солонцеватых почвах сухостепной и лесостепной зон и проанализировать, как изменяются эти показатели при мелиорации солонцов в разных зонах с использованием специального показателя для оценки физико-химических условий развития солонцового процесса (балл $B$ ), предложенного Н.Б. Хитровым.

\section{ОБЪЕКТЫ И МЕТОДЫ}

Для достижения поставленной цели использовали данные анализов целинных и агрогенноизмененных солонцов и солонцеватых почв с разным содержанием обменного натрия и степенью гидроморфизма из Костанайской (Республика Казахстан), Астраханской, Воронежской, Волгоградской, Омской, Новосибирской областей. Изучали мелиорированные солонцы как с полностью разрушенным солонцовым профилем, так и с частично сохранившимся солонцовым горизонтом. Проанализированы образцы из 21 разреза, из них 14 расположено в сухостепной, 7 в лесостепной зоне. По режиму увлажнения, большая часть почв сухостепной зоны относилась к степным почвам, почвы двух разрезов - луговостепным. В лесостепной зоне все почвы по режиму увлажнения относились к лугово-степным. Классификационная принадлежность почв в соответствие с классификацией почв (1977) представлена в таблице.

В образцах определены состав обменных оснований по методу Пфеффера в модификации Молодцова и Игнатовой, ионносолевой состав водной вытяжки и состав растворов в фильтратах из водонасыщенных почвенных паст. В ряде образцов анализ растворов из водонасыщенных паст не проводили. Удельную электропроводность измеряли кондуктометром “Эксперт-002” или получали расчетным путем (Воробьева, 1998; Хитров, Понизовский, 1990; McNeal et al., 1970). Кроме того, в некоторых образцах опре- 
Бюллетень Почвенного института им. В.В. Докучаева. 2016. Вып. 84.

Показатели физико-химических условий развития солонцового процесса $[B]$ в целинных и агрогенноизмененных почвах солонцовых комплексов сухостепной и лесостепной зон

\begin{tabular}{|c|c|c|c|c|c|}
\hline $\begin{array}{c}\text { Горизонт, } \\
\text { глубина, см }\end{array}$ & $\begin{array}{c}\text { Сумма } \\
\text { солей, } \\
\%\end{array}$ & $\mathrm{pH}$ & $\begin{array}{c}\text { Содержание об- } \\
\text { менного натрия, } \\
\text { \% от суммы } \\
\text { катионов }\end{array}$ & $B$ & $\begin{array}{c}\text { Время за- } \\
\text { держки } \\
\text { набухания, } \\
\text { мин }\end{array}$ \\
\hline
\end{tabular}

\section{Сухостепная зона}

Волгоградская область, Городищенский район, п. Самофаловский. Солонец каштановый солончаковатый высококарбонатный глубокогипсовый средний средненатриевый, 1973 г. (целина)
$\mathrm{A}_{1}+\mathrm{A}_{2}(0-10)$
0.31
8.25
0.30
8.20
21.3
27.8
$\mathrm{B}_{1} 2(20-30)$
0.33
8.60
42.1

\begin{tabular}{r|c}
$<1$ & Не опр. \\
2 & $»$ \\
4 & $»$
\end{tabular}

Солонец каштановый солончаковатый высококарбонатный глубокогипсовый средний малонатриевый, 1997 г. (целина)
$\mathrm{B}_{1} 1(10-22)$
0.05
7.88
0.10
8.28
3.1
3.0
$\mathrm{B}_{2} \mathrm{~K}(30-40)$
$0.07 \quad 8.53$
3.8
\begin{tabular}{l|l}
0 & 0 \\
0 & 0 \\
0 & 0
\end{tabular}

Светло-каштановая высококарбонатная солонцеватая почва, 1973 г. (целина)
$\mathrm{A}_{1}(0-10)$
$\mathrm{B}_{1}$ сн (10-20)

\begin{tabular}{l|l|}
0.08 & 7.20 \\
0.09 & 7.90 \\
0.08 & 7.95
\end{tabular}
5.0
3.2
4.0
\begin{tabular}{l|c}
0 & Не опр. \\
0 & $»$ \\
0 & $»$
\end{tabular}

Светло-каштановая высококарбонатная солонцеватая почва, 1997 г. (целина)
$\mathrm{A}_{1}(0-13)$
$\mathrm{B}_{1}$ сн (13-31)
0.02
0.02
0.02
7.12
7.29
$\mathrm{B}_{1}(31-45)$
\begin{tabular}{l|l|l|}
0.02 & 8.31
\end{tabular}
\begin{tabular}{l|l} 
Не опр. & 0 \\
1.2 & 0 \\
Не опр. & 0
\end{tabular}
Не опр.
》

Солонец каштановый солончаковатый карбонатный средний малонатриевый мелиорированный с сохранившимся солонцовым горизонтом, 1997 г. (многолетний полевой опыт)

\begin{tabular}{l|l|l|l|l|c} 
А пах (0-5(24)) & 0.03 & 6.49 & 1.8 & 0 & $<1$ \\
$\mathrm{~B}_{1}$ пах (8-42) & 0.03 & 7.42 & 8.5 & 0 & Нет \\
$\mathrm{B}_{1}(42-55)$ & 0.08 & 6.74 & 5.7 & 0.7 & Нет \\
$\mathrm{B}_{2}(38(42)-55)$ & 0.12 & 8.81 & 14.0 & 0 & $<1$
\end{tabular}

Солонец каштановый солончаковатый карбонатный средний малонатриевый мелиорированный с разрушенным солонцовым горизонтом, 1997 г. (многолетний полевой опыт)

\begin{tabular}{|c|c|c|l|c|c} 
А пах 1к (1.5-10(18)) & 0.05 & 7.83 & 2.9 & 0 & 0 \\
А пах 2к (10(18)-25(44)) & 0.09 & 8.25 & 8.1 & 0.5 & $<1$ \\
А пах 3 (25(44)-32(55)) & 0.10 & 8.45 & 9.8 & 0 & 0 \\
\hline
\end{tabular}


Бюллетень Почвенного института им. В.В. Докучаева. 2016. Вып. 84.

\begin{tabular}{|c|c|c|c|c|c|}
\hline $\begin{array}{c}\text { Горизонт, } \\
\text { глубина, см }\end{array}$ & $\begin{array}{c}\text { Сумма } \\
\text { солей, } \\
\%\end{array}$ & $\mathrm{pH}$ & $\begin{array}{c}\text { Содержание об- } \\
\text { менного натрия, } \\
\text { \% от суммы } \\
\text { катионов }\end{array}$ & $B$ & $\begin{array}{c}\text { Время за- } \\
\text { держки } \\
\text { набухания, } \\
\text { мин }\end{array}$ \\
\hline $\mathrm{BC}(36(55)-60))$ & 0.12 & 8.99 & $\begin{array}{c}15.1 \\
\text { Волгоградская область, Октябрьский район. п. Абганерово }\end{array}$ \\
Солонец каштановый солончаковатый высококарбонатный глубоко- \\
гипсовый корковый малонатриевый (целина) \\
$\mathrm{A}_{1}+\mathrm{A}_{2}(0-4)$ \\
$\mathrm{B}_{1} 1(4-17)$ & 0.08 & 7.65 & 10.1 & 0 & Не опр. \\
$\mathrm{B}_{1} 2(17-31)$ & 0.06 & 7.85 & 12.8 & 1 & $»$
\end{tabular}

Светло-каштановая высококарбонатная солонцеватая почва (целина)

\begin{tabular}{l|c|c|c|c|c}
$\mathrm{A}_{1}(0-9)$ & 0.04 & 7.80 & 8.44 & 0.5 & Не опр. \\
$\mathrm{B}_{1} 1$ (9-18) & 0.04 & 7.55 & 4.8 & 0.5 & $»$ \\
$\mathrm{~B}_{1} 2$ (18-32) & 0.03 & 7.50 & 2.8 & 0.5 & ”
\end{tabular}

Волгоградская область, Николаевский район, п. Степновка

Солонец лугово-степной высокосолончаковатый сильнозасоленный мелкий многонатриевый (целина)

\begin{tabular}{l|c|c|c|c|c}
$\mathrm{A}_{1}+\mathrm{A}_{2}(1-9)$ & 0.08 & 7.7 & 12.4 & 2 & 0 \\
$\mathrm{~B}_{1}(9-23)$ & 0.15 & 8.5 & 31.9 & 5 & 6 \\
$\mathrm{~B}_{2} 1 \kappa, \Gamma(23-40)$ & 0.80 & 9.1 & 48.2 & 4 & $<6$ \\
$\mathrm{~B}_{2} 2 \kappa(30-42)$ & 0.61 & 9.1 & 48.1 & 5 & $<6$ \\
$\mathrm{~B}_{2} 3 \kappa, \Gamma(40-67)$ & 1.54 & 8.6 & 28.5 & 0 & 0
\end{tabular}

Солонец лугово-степной высокосолончаковатый сильнозасоленный мелкий многонатриевый постирригационный плантажированный (пашня)
А пах 1к (0-10(14))
0.06
8.5
12.4
А пах 2к (10(14)-23)
0.08
8.8
31.9
0.12
9.3
48.2
$\mathrm{B}_{2} 1 \kappa(32-44)$
0.17
9.7
48.1
1.40
8.8
28.5

\begin{tabular}{|c|c}
2 & 0 \\
$5-4$ & 0 \\
$4-1$ & 0 \\
$5-2$ & $<6$ \\
0 & Не опр.
\end{tabular}

Астраханская область, Черноярский район, с. Черный Яр.

Солонец каштановый солончаковый высококарбонатный глубокогипсовый мелкий малонатриевый (целина)
$\mathrm{A}_{1}+\mathrm{A}_{2}(0-10)$

\begin{tabular}{|c|c|} 
Не & Нет \\
опр. & дан- \\
$0.23 *$ & ных \\
$0.55^{*}$ &
\end{tabular}
3.9
0 Не опр.
$\mathrm{B}_{1}(10-25)$
$\mathrm{B}_{2}(25-50)$

Светло-каштановая высококарбонатная солонцеватая (целина)

\begin{tabular}{|l|c|c|c|c|c|}
$\mathrm{A}_{1} 1(0-5)$ & $0.06^{*}$ & Нет & 1.6 & 0 & Не опр. \\
$\mathrm{A}_{1} 2(5-15)$ & $0.06^{*}$ & дан- & 0.9 & 0 & $»$ \\
$\mathrm{~B}_{1}$ сн (15-(25)33) & $0.19^{*}$ & ных & 1.1 & 0 & $»$ \\
\hline
\end{tabular}


Бюллетень Почвенного института им. В.В. Докучаева. 2016. Вып. 84.

\begin{tabular}{|c|c|c|c|c|c|}
\hline $\begin{array}{l}\text { Горизонт, } \\
\text { глубина, см }\end{array}$ & $\begin{array}{c}\text { Сумма } \\
\text { солей, } \\
\%\end{array}$ & $\mathrm{pH}$ & $\begin{array}{l}\text { Содержание об- } \\
\text { менного натрия, } \\
\text { \% от суммы } \\
\text { катионов }\end{array}$ & $B$ & $\begin{array}{l}\text { Время за- } \\
\text { держки } \\
\text { набухания, } \\
\text { мин }\end{array}$ \\
\hline \multicolumn{6}{|c|}{$\begin{array}{l}\text { Казахстан, Костанайская область, Семиозерный район } \\
\text { ц каштановый солончаковый высококарбонатный глубокогип- } \\
\text { совый корковый малонатриевый (целина) }\end{array}$} \\
\hline$A_{2}(0-2)$ & $0.03 *$ & 6.64 & \multicolumn{3}{|c|}{ Не опр. } \\
\hline $\mathrm{B}_{1} 1(2-9)$ & $0.13^{*}$ & 7.28 & 9.6 & 0 & Не опр. \\
\hline $\mathrm{B}_{1} 2(9-25)$ & $0.35^{*}$ & 8.30 & 18.4 & 0 & $\gg$ \\
\hline $\mathrm{B}_{2} \mathrm{~K}(25-69)$ & $1.13 *$ & 8.11 & 19.0 & 0 & $\gg$ \\
\hline \multicolumn{6}{|c|}{$\begin{array}{c}\text { Солонец каштановый степной солончаковый высококарбонатный глу- } \\
\text { бокогипсовый мелкий малонатриевый (целина) }\end{array}$} \\
\hline$A_{1}+A_{2}(2-5(12)$ & $|0.03 *|$ & 6.58 & 3.2 & 0 & Не опр. \\
\hline $\mathrm{B}_{1}(5) 12-24(37)$ & $0.14^{*}$ & 8.64 & 14.6 & 0 & $»$ \\
\hline $\mathrm{B}_{2}(18) 31-43$ & $0.39 *$ & 9.10 & 19.6 & 0 & $\gg$ \\
\hline \multicolumn{6}{|c|}{ Лесостепная зона } \\
\hline \multicolumn{6}{|c|}{$\begin{array}{c}\text { Воронежская область, Таловский район,Каменная степь** } \\
\text { Солонец лугово-черноземный высокосолончаковатый сильнозасолен- } \\
\text { ный средний многонатриевый (залежь) }\end{array}$} \\
\hline $\mathrm{B}_{1} 1(1-6)$ & 0.07 & 7.07 & 12.7 & 3 & $<6$ \\
\hline $\mathrm{B}_{1} 2(\mathrm{C}$ & 0.06 & 6.94 & & 4 & $<6$ \\
\hline $\mathrm{B}_{1} 3$ пах1 (17-24) & 0.09 & 7.15 & 22.9 & 4 & $<6$ \\
\hline $\mathrm{B}_{1}(24-34)$ & 0.18 & 7.60 & 26.2 & $4-5$ & 0 \\
\hline \multicolumn{6}{|c|}{ Лугово-черноземная среднесолонцеватая (залежь) } \\
\hline Ад $(0-4)$ & 0.20 & $\gg$ & 13.6 & 1 & 0 \\
\hline А пах $1(4-10)$ & 0.19 & $\gg$ & 13.2 & $1-2$ & 0 \\
\hline А пах $1(10-17)$ & 0.16 & $\gg$ & 11.3 & $1-2$ & 0 \\
\hline $\mathrm{A} \operatorname{пах}_{2}(17-30)$ & 0.11 & $\gg$ & 12.0 & 2 & 0 \\
\hline А пах $2(30-45)$ & 0.10 & $»$ & 11.1 & $1-2$ & $<6$ \\
\hline \multicolumn{6}{|c|}{ Омская область Омский район } \\
\hline \multicolumn{6}{|c|}{$\begin{array}{l}\text { Солонец лугово-черноземный высокосолончаковатый содово- } \\
\text { лльфатный сильнозасоленный корковый многонатриевый (целина) }\end{array}$} \\
\hline $\mathrm{B}_{1} 1(0-17(20))$ & 0.11 & 7.23 & 26.6 & 5 & $<6$ \\
\hline $\mathrm{B}_{1} 2(17(20)-34)$ & 0.28 & 8.66 & 46.3 & 7 & 152 \\
\hline $\mathrm{B}_{2}(34-48)$ & 0.49 & 9.24 & 51.9 & 7 & 76 \\
\hline ВСк (48-70) & 0.41 & 9.82 & 51.9 & 8 & 60 \\
\hline \multicolumn{6}{|c|}{$\begin{array}{c}\text { Солонец лугово-черноземный среднесолончаковатый сульфатно- } \\
\text { содовый слабозасоленный средний средненатриевый с сохранившимся } \\
\text { солонцовым горизонтом (залежь) }\end{array}$} \\
\hline А пах (10-20) & 0.04 & 6.61 & 6.09 & 2 & $<6$ \\
\hline $\mathrm{B}_{1}(20-50)$ & 0.10 & 8.14 & 24.83 & 5 & 40 \\
\hline
\end{tabular}


Бюллетень Почвенного института им. В.В. Докучаева. 2016. Вып. 84.

\begin{tabular}{|c|c|c|c|c|c|}
\hline $\begin{array}{c}\text { Горизонт, } \\
\text { глубина, см }\end{array}$ & $\begin{array}{c}\text { Сумма } \\
\text { солей, } \\
\%\end{array}$ & $\mathrm{pH}$ & $\begin{array}{c}\text { Содержание об- } \\
\text { менного натрия, } \\
\text { \% от суммы } \\
\text { катионов }\end{array}$ & $B$ & $\begin{array}{c}\text { Время за- } \\
\text { держки } \\
\text { набухания, } \\
\text { мин }\end{array}$ \\
\hline $\mathrm{B}_{2}(50-70)$ & 0.22 & 9.35 & 30.79 & 6 & 150 \\
\hline ВСк (70-90) & 0.24 & 9.70 & 32.27 & 6 & 12 \\
\hline \multicolumn{6}{|c|}{$\begin{array}{l}\text { Солонец лугово-черноземный солончаковый содово-сульфатный сильно- } \\
\text { засоленный средний с разрушенным солонцовым горизонтом (залежь) }\end{array}$} \\
\hline А пах (0-24) & 0.21 & 8.46 & 6.1 & 2 & $<6$ \\
\hline $\mathrm{B}_{3}(24-45)$ & 0.46 & 9.73 & 24.8 & 5 & 40 \\
\hline $\mathrm{B}_{4} \mathrm{~K}(45-90)$ & 0.30 & 10.02 & 30.8 & 6 & 150 \\
\hline ВСк $(90-100)$ & 0.28 & 9.82 & 32.3 & 6 & 12 \\
\hline \multicolumn{6}{|c|}{$\begin{array}{c}\text { Солонец лугово-черноземный средний хлоридно-гидрокарбонатный } \\
\text { средний малонатриевый }\end{array}$} \\
\hline $\mathrm{B}_{1} 1(16-31)$ & 0.07 & 7.60 & 19.3 & 3 & 7 \\
\hline $\mathrm{B}_{1} 2(31-55)$ & 0.17 & 9.04 & 24.2 & 3 & 10 \\
\hline $\mathrm{BC}(55-95)$ & 0.17 & 9.24 & 26.9 & 3 & 13 \\
\hline \multicolumn{6}{|c|}{ Новосибирская область } \\
\hline \multicolumn{6}{|c|}{$\begin{array}{c}\text { Солонец полугидроморфный лугово-черноземный солончаковый содо- } \\
\text { вый среднезасоленный корковый средненатриевый*** }\end{array}$} \\
\hline $\mathrm{B}_{1} 1(1-8)$ & 0.20 & 7.90 & 18.7 & 1 & 30 \\
\hline $\mathrm{B}_{1} 2(8-15)$ & 0.27 & 8.74 & 32.1 & $5-6$ & 30 \\
\hline $\mathrm{B}_{1} 3(15-25)$ & 0.31 & 9.35 & 43.0 & 8 & 40 \\
\hline $\mathrm{B}_{2}(25-31)$ & 0.28 & 9.46 & 47.0 & 8 & 0 \\
\hline
\end{tabular}

* Сумма токсичных солей, \%.

** Образцы Н.Б. Хитрова.

*** Образцы Т.Н. Елизаровой

определяли особенности кинетики набухания почв с использованием прибора набухания грунтов, совмещенного с самописцем. По исследованиям В.А. Грачева, Э.А. Корнблюма (1982) на кривой набухания образцов солонцовых горизонтов имеет место задержка набухания в образцах солонцового горизонта.

\section{РЕЗУЛЬТАТЫ И ОБСУЖДЕНИЕ}

Как известно, диагностическими критериями для выделения солонцов как самостоятельного типа почв являются наличие профиля элювиально-иллювиального типа (по илистой фракции) и типообразующего солонцового горизонта. Строение профиля всех 
Бюллетень Почвенного института им. В.В. Докучаева. 2016. Вып. 84.

изученных целинных солонцов полностью соответствует описанию данного типа почв.

По содержанию обменного натрия проанализированные целинные автоморфные солонцы сухостепной зоны относились к мало-, средненатриевым, лугово-степные - к многонатриевым. Целинные лугово-степные солонцы лесостепной зоны представлены мало-, средне- и многонатриевыми солонцами. По содержанию легкорастворимых солей целинные солонцы варьируют от незасоленных до сильнозасоленных. По химизму засоления солонцы сухостепной зоны отличаются от солонцов лесостепной зоны. Первые имеют сульфатно-хлоридное и хлоридно-сульфатное засоление. Тогда как в солонцах лесостепной зоны часто отмечается наличие соды.

Величина показателя $B$ в солонцовых горизонтах целинных степных каштановых малонатриевых солонцов и в солонцеватых горизонтах степных светло-каштановых солонцеватых почв сухостепной зоны варьирует от 0 до 1, т.е. физико-химические свойства почв не благоприятны для развития солонцового процесса. В этих образцах отсутствует задержка на кривой кинетики набухания.

В целинных степных средненатриевых солонцах балл $B$ варьирует от 2 до 4, что соответствует слабой степени выраженности солонцового процесса. В солонцовом горизонте также имеет место задержка набухания.

В целинном лугово-степном каштановом многонатриевом солонце (Николаевский район, Волгоградской области) с уровнем залегания минерализованных грунтовых вод около 3 м в солонцовом горизонте балл $B$ равен 4-5, что соответствует сильной степени выраженности солонцового процесса. На кривой набухания солонцового горизонта отмечена шестиминутная задержка. В подсолонцовых гор. $\mathrm{B}_{2} 1 \kappa, \Gamma$ и $\mathrm{B}_{2} 2 \kappa$ соотношение между содержанием водорастворимых солей и обменного натрия также оказалось благоприятно для развития солонцового процесса. Имеет место и задержка набухания в этих горизонтах.

Если сравнить степень выраженности солонцового процесса в степных целинных и агрогенноизмененных солонцах с разрушенным солонцовым профилем, видно, что в пахотном и подпахотном горизонтах агрогенноизмененных солонцов отсутствуют 
Бюллетень Почвенного института им. В.В. Докучаева. 2016. Вып. 84.

физико-химические условия для развития солонцового процесса, балл $B=0$. Не обнаружено благоприятных физико-химических условий для развития солонцового процесса и в мелиорированном солонце с частично сохранившимся солонцовым горизонтом. Тогда как в постирригационном лугово-степном солонце Волгоградской области небольшой риск развития солонцового процесса присутствует.

Необходимо отметить, что во всех агрогенноизмененных солонцах сухостепной зоны после проведения мелиоративных мероприятий морфологических признаков восстановления и развития солонцового процесса не отмечено.

Результаты расчетов балла $B$ и определение кинетики набухания в целинных черноземных лугово-степных мало-, средне- и много натриевых солонцах лесостепной зоны показали, что в солонцовых и солонцеватых горизонтах величина балла $B$ варьирует от 3 в малонатриевых солонцах (слабая степень выраженности солонцового процесса) до 7 в многонатриевых (сильная степень выраженности солонцового процесса). На кривой набухания в этих образцах наблюдается задержка от 7-10 мин в малонатриевом солонце до 152 мин - в многонатриевом.

В целинных лугово-черноземных почвах по мере увеличения солонцеватости балл $B$ в солонцеватом горизонте увеличивается от 1 до 6, задержка набухания в этих почвах оказалась одинаковой -6 мин.

Во всех проанализированных агрогенноизмененных солонцах и лугово-черноземных солонцеватых почвах лесостепной зоны Воронежской области сохраняются благоприятные физикохимические условия для протекания солонцового процесса. Балл $B$ в солонцеватых горизонтах этих почв достигает 4-5, и имеет место задержка набухания в этих горизонтах. В агроизмененных солонцах Омской области, несмотря на проведенные мелиоративные мероприятия, отмечается высокий балл $B$ и задержка набухания. Эти показатели незначительно отличаются от значений, полученных для целинных почв.

Как можно видеть, что солонцовый процесс в целинных автоморфных солонцах сухостепной зоны, в которых нет влияния грунтовых вод, в настоящее время либо отсутствует, либо выражен слабо. Проведенные мелиоративные мероприятия приводят к 
Бюллетень Почвенного института им. В.В. Докучаева. 2016. Вып. 84.

уменьшению содержания легкорастворимых солей и обменного натрия в этих почвах, что не способствует реставрации в них солонцового процесса. В то же время солонцовый процесс активен в агрогенноизмененных многонатриевых лугово-степных солонцах каштановой зоны с глубиной залегания грунтовых вод 3.5 м. Проведенные планировки с разрушением солонцового горизонта и орошение не привели к значительному изменению содержания в верхних горизонтах постирригационных солонцов содержания солей и обменного натрия. Что предполагает возможность реставрации солонцового процесса в этих почвах.

В лесостепной зоне, где грунтовые воды могут оказывать влияние на почвы, солонцовый процесс активен как в целинных, так и в агрогенноизмененных почвах, это подтверждают расчеты балла $B$. Поэтому можно утверждать, что риск реставрации солонцового процесса в этих почвах намного выше, чем в почвах сухостепной зоны.

Необходимо отметить, что такие свойства почв, как содержание легкорастворимых солей и обменного натрия в почвенном поглощающем комплексе могут меняться в зависимости от цикличного изменения погодных условий. Это хорошо показано в работах Еремченко (1997), Семендяевой (2007), Березина (2009), Голованова, Сотневой (2009). В одних случаях это происходит из-за изменения количества выпадающих осадков (Еремченко, 1997; Голованов, Сотнева, 2009), в других - за счет влияния температурного фактора (Семендяева, 2007; Березин, 2009).

Для того, чтобы показать насколько могут различаться по значению балла целинные почвы одного и того же участка в разные годы отбора образцов в таблице приведены данные значений балла $B$, рассчитанные для образцов, отобранных в 1973 г. (период лет с количеством осадков равных или ниже средней многолетней) и 1997 гг. (в период лет с преобладанием осадков равных или выше средней многолетней). По данным анализов солонцы 1973 г. относились к средненатриевым, балл $B$ в них варьировал от 2 до 4, в 1997 г. по содержанию обменного натрия эти почвы были диагностированы как малонатриевые, балл $B=0$. Полученные результаты показывают, что при проведении мониторинга изменения свойств мелиорированных почв сухостепной зоны всегда необхо- 
Бюллетень Почвенного института им. В.В. Докучаева. 2016. Вып. 84.

димо учитывать погодные условия в год отбора образцов и в предыдущие годы.

Е.Н. Иванова и В.М. Фридланд (1954) считали, что формирование почвенного покрова Прикаспийской низменности проходило в несколько этапов по мере изменения водного режима почв, последнее связано с изменением паводкового обводнения, снижением уровня грунтовых вод при расчленении рельефа и образованием дренирующих систем. По их мнению, по мере углубления залегания грунтовых вод при развитии степных комплексов солонцы переходили в остаточные степные солонцы.

По данным палеопочвоведов почвенный покров исследуемых сухостепных территорий России и Казахстана сложился 5-6 тыс. лет тому назад. За последний 3500-летний период почвы этих территорий испытывали процессы рассоления. Солонцовые признаки перешли в ряде случаев в реликтовые или остаточные (Демкин, Иванов, 1985; Иванов и др., 1986; Демкин, Лукашов, 1987; Иванов, Демкин, 1992; Демкин и др., 2007, 2008).

Полученные нами данные экспериментально подтвердили вышеприведенные высказывания. Действительно в обследованных целинных малонатриевых степных солонцах и солонцеватых почвах сухостепной зоны в настоящее время солонцовый процесс не активен, в средне- и многонатриевых солонцах он диагностируется, но имеет слабую степень выраженности. Агрогенное воздействие не вызывает активизацию солонцового процесса. Это объясняется тем, что в степных солонцах сухостепной зоны мелиорация приводит к рассолению почв, уменьшению содержания обменного натрия. Подтягивание небольшого количества солей из срединных горизонтов в периоды экстремального иссушения почв не могут сильно повлиять на увеличение активности развития солонцового процесса. Влияние грунтовых вод в этих почвах на процессы накопления солей и изменение содержания обменного натрия отсутствует. Количество выпадающих осадков невелико, и они не могут способствовать перемещению илистой фракции по профилю почв.

В лугово-степных солонцах лесостепной зоны степень выраженности солонцового процесса в много- и средненатриевых солонцах высокая, в малонатриевых солонцах она ниже. При мелиорации лугово-степных солонцов при разрушении солонцового 
Бюллетень Почвенного института им. В.В. Докучаева. 2016. Вып. 84.

горизонта, являвшегося своеобразным барьером для подъема солей, влияние минерализованных грунтовых вод на почвенный профиль агрогенноизмененных почв может даже возрасти. Мелиорация приводит к уменьшению содержания легкорастворимых солей и обменного натрия в верхней толще почв. В то же время близкое залегание грунтовых вод может поддерживать соотношение между содержанием легкорастворимых солей и обменного натрия на благоприятном для протекания солонцового процесса уровне. В присутствие карбонатов и обменного натрия в почвах создаются условия для образования соды, также провоцирующей развитие солонцового процесса. Количество выпадающих осадков в лесостепной зоне выше, что может способствовать иллювиированию илистых частиц.

\section{ВЫВОДЫ}

1. Солонцовый процесс в целинных автоморфных почвах сухостепной зоне в настоящее время выражен слабо из-за отсутствия в почвах условий для пептизации и передвижения илистой фракции. Мелиорация автоморфных почв солонцовых комплексов в зоне сухих степей приводит к улучшению физико-химических свойств этих почв: уменьшению содержания легкорастворимых солей и обменного натрия. Риск реставрации солонцового процесса и солонцового профиля в этих почвах маловероятен.

2. В лесостепной зоне при близком залегании грунтовых вод, часто с присутствием соды, солонцовый процесс в целинных почвах достаточно активен. Мелиорация солонцов не приводит к коренному улучшению физико-химических свойств этих почв. Риск реставрации солонцового процесса в этих почвах намного выше, чем в почвах полупустынной и сухостепной зон.

3. Различия в постмелиоративном развитии солонцов в разных зонах связано с исходной степенью выраженности солонцового процесса в целинных почвах в настоящее время.

Благодарность. Работа выполнена при поддержке гранта РФФИ №15-04-08528.

\section{СПИСОК ЛИТЕРАТУРЫ}

1. Бабушкин В.М., Баранов А.И. Мелиорация темно-каштановых солонцовых почв южного региона России. Новочеркасск, 2007. 211 с. 
Бюллетень Почвенного института им. В.В. Докучаева. 2016. Вып. 84.

2. Березин Л.В. Особенности мелиорации сезонно-промерзающих почв черноземно-солонцовых комплексов Ишимской лесостепи // Докл. Омского отделения Межд. Акад. наук экологии и безопасности жизнедеятельности. Омск: МАНЭБ, 2009. Т. 8. Вып. 2(15). С. 42-57.

3. Голованов А.И., Сотнева Н.И. Математическое моделирование влагои солепереноса в геосистемах солонцовых комплексов Северного Прикаспия // Почвоведение. 2009. № 3. С. 273-289.

4. Грачев B.А., Корнблюм Э.А. Кинетика набухания и набухаемость почв солонцовых комплексов и солодей Заволжья // Почвоведение. 1982. № 1. C. 55-66.

5. Воробьева Л.А. Химический анализ почв. М.: Изд-во Моск. ун-та, 1998. $272 \mathrm{c}$.

6. Демкин В.А., Иванов И.В. Развитие почв Прикаспийской низменности в голоцене. Пущино, 1985. $164 \mathrm{c}$.

7. Демкин В.А., Лукашов А.А. О скорости и направленности почвообразовательного процесса в зоне сухих степей в голоцене // Почвоведение. 1987. № 6. С. 5-14.

8. Демкин В.А., Борисов А.В., Демкина Т.Э., Ельцов М.В. Эволюция почв солонцового комплекса Нижнего Поволжья за историческое время // Пространственно-временная организация почвенного покрова: теоретические и прикладные аспекты. Мат-лы. Междунар. науч. конф. СПб., 2007. C. 214-217.

9. Демкин В.А., Каширская Н.Н., Демкина Т.С., Хомутова Т.Э., Ельцов М.В. Палеопочвенные исследования курганов в долине р. Иловля (Приволжская возвышенность) // Почвоведение. 2008. № 2. С. 133-145.

10.Еремченко О.3. Природно-антропогенные изменения солонцовых почв в Южном Зауралье. Пермь: Изд-во Пермского ун-та, 1997. 317 с.

11.Иванов И.В., Демкин В.А., Губин С.В. Развитие ландшафтов и почв степного Поволжья в голоцене // Природа и хозяйственная деятельность в Нижнем Поволжье. Волгоград, 1986. С. 21-27.

12.Иванов И.В., Демкин В.А. Эволюция почв // Почвенно-экологические проблемы в степном земледелии: Сб. науч. тр. Пущино, 1992. С. 30-44. 13.Иванова E.Н., Фридланд В.М. Почвенные комплексы сухих степей и их эволюция // Вопросы улучшения кормовой базы в степной, полупустынной и пустынной зонах СССР. М., АН СССР, 1954. С. 162-190.

14.Классификация и диагностика почв СССР. М.: Колос, 1977. 224 с.

15.Любимова И.Н. Агрогеннопреобразованные почвы солонцовых комплексов сухостепной и полупустынной зон: Автореф. ...дис. д. с.-х. н. M., 2003. $48 \mathrm{c}$.

16.Новикова А.Ф., Габченко М.В., Беспалов В.П. Изменение почв солонцовых комплексов Ергеней в результате длительного антропогенного воздействия // Почвоведение. 2009. № 4. С. 391-402. 
Бюллетень Почвенного института им. В.В. Докучаева. 2016. Вып. 84.

17.Паракшин Ю.П. Естественная и антропогенная эволюция солонцовых ландшафтов // Генезис и мелиорация почв солонцовых комплексов. М.: Россельхозакадемия. 2008. С. 72-75.

18. Семендяева Н.В. Проблемы солепередвижения при мелиорации солонцов юга Западной Сибири // Организация почвенных систем. Т. 2. Пущино, 2007. С. 339-342.

19.Хитров Н.Б. Выбор диагностических критериев существования и степени выраженности солонцового процесса в почвах // Почвоведение. 2004. № 1. C. 18-31.

20.Хитров Н.Б., Чевердин Ю.И. Морфологические признаки проявления процессов постагрогенного и постмелиоративного развития почв черноземных солонцовых комплексов Каменной степи // Разнообразие почв Каменной степи. М.: Почв. ин-т им. В.В. Докучаева, 2009. С. 327-354. 21.Хитров Н.Б., Понизовский А.А. Руководство по лабораторным методам исследования ионно-солевого состава нейтральных и щелочных минеральных почв. М.: Почв. ин-т им. В.В. Докучаева, 1990. 236 с.

22.Bresler E., McNeal B.L., Carter D.L. Saline and Sodic Soils. PrinciplesDynamics-Modeling, 1982. $236 \mathrm{p}$.

23.McNeal B.L., Coleman N.T. Effect of solution composition on soil hydraulic conductivity // Soil Sci. Soc. Am. Proc. 1966. V. 30. № 3. P. 308-312.

24.Rhoades J.D., Ingvalson R.D. Macroscopic swelling and hydraulic conductivity properties of four vermiculitic soils // Soil Sci. Soc. Am. Proc. 1969. V. 33. № 3. P. 364-369.

25.Naghohinen-Pour B., Kunze G.W., Carson C.D. The effect of electrolyte composition on hydraulic conductivity for certain Texas soils // Soil Sci. 1970. V. 110. № 2. P. 124-127.

\title{
THE DEGREE OF INTENSIVITY OF SOLONETZIC PROCESS WITHIN THE VIRGIN SOILS AND SOILS WITH AGROGENIC TRANSFORMATION IN SOLONETZIC COMPLEXES OF FRORES-STEPPE AND DRY STEPPE ZONES
}

\author{
I. N. Lyubimova ${ }^{1}$, I. A. Salpagarova ${ }^{2}$, V. V. Khan ${ }^{2}$ \\ ${ }^{1}$ V.V. Dokuchaev Soil Science Institute, \\ Russia, 119017, Moscow, Pyzhevskii 7, bld. 2 \\ ${ }^{2}$ Lomonosov Moscow State University, \\ Russia, 119991, Moscow, 1 Leninskiye Gory
}

The comparative assessment of the degree of solonetzic processes was conducted for the soils of solonetzic complexes in forest steppe and dry steppe 
zones. We analized virgin solonetzes and solonetzes affected by the agrogenic transformation with different content of exchangeable sodium and with different hydromorphism degree from Kostanai (Kazakhstan Republic), Astrakhan, Voronezh, Volgograd, Omsk, and Novosibirsk regions. We investigated meliorated solonetzes as with completely destructed profile, and with partically preserved solonetzic layer. For that purposes we used special $B$-grade, suggested by N.B. Khitrov. It is shown that solonetzic process is poorly manifested in virgin automorphic soils of dry steppe zone. The physical and chemical properties which are created after melioration do not encourage the restoration of solonetzic process. The solonetzic process in meadow-steppe solonetzes of dry steppe and, especially, forest steppe zones is active at the present moment. The melioration improves the properties of these soils, but it is insufficient for the destruction of physical and chemical conditions favourable for restoration of solonetzic process. The difference in post-meliorative development of solonetzes is stipulated by the initial degree of manifestation of solonetzic process in virgin soils at the present.

Keywords: solonetzes, solonetzic soils, solonetzic process, forest steppe zone, dry steppe zone. 